\title{
PENGARUH PEMANFAATAN TEKNOLOGI INFORMASI, KESESUAIAN TUGAS, DAN EFEKTIVITAS SIA TERHADAP KINERJA KARYAWAN PADA KOPDIT TRI
} TUNGGAL TUKA

\author{
Agustinus I Ketut Alexsdipa ${ }^{1}$ I Made Pande Dwiana Putra ${ }^{2}$
}

\section{Article history:}

Submitted: 30 Juli 2021

Revised: 26 Agustus 2021

Accepted: 5 September 2021

\section{Keywords:}

Information Technology;

Task Suitability;

Accounting Information

Systems;

EmployeePerformance;

\section{Kata Kunci:}

Teknologi Informasi;

Kesesuaian Tugas;

Sistem Informasi Akuntansi;

Kinerja Karyawan;

\section{Koresponding:}

Fakulas Ekonomi dan Bisnis

Universitas Udayana, Bali,

Indonesia

Email:

alexsdipa28@gmail.com

\section{Abstract}

The development of technology-based information systems requires companies and organizations to make changes in the information sector so that they do not lag behind in absorbing information. Accounting is a tool in managing accounting and financial data, so an information system is needed to be able to convey this information to those in need, namely the accounting information system. This study aims to obtain empirical evidence of the effect of Information Technology Utilization, Task Suitability, and Effectiveness of Accounting Information Systems on Employee Performance at the Tri TunggalTuka Credit Cooperative. The sampling methodused in this research is the saturated sampling technique, where the saturated sampling technique is used as the sample. Data collection methods used in this study werequestionnaires and interviews. The data analysis techniques in this study are Descriptive Statistical Analysis, ClassicalAssumption Test, Multiple Linear Regression Analysis, Model Feasibility Test (F Test), Hypothesis Test (t Test), and Coefficient of Determination Test $\left(R^{\wedge} 2\right)$. The results in the study concluded that the use of information technology, task suitability, and the effectiveness of accounting information systems had a positive effect on employee performance of the Tri TunggalTuka Credit Cooperative.

\begin{tabular}{|c|}
\hline Abstrak \\
\hline 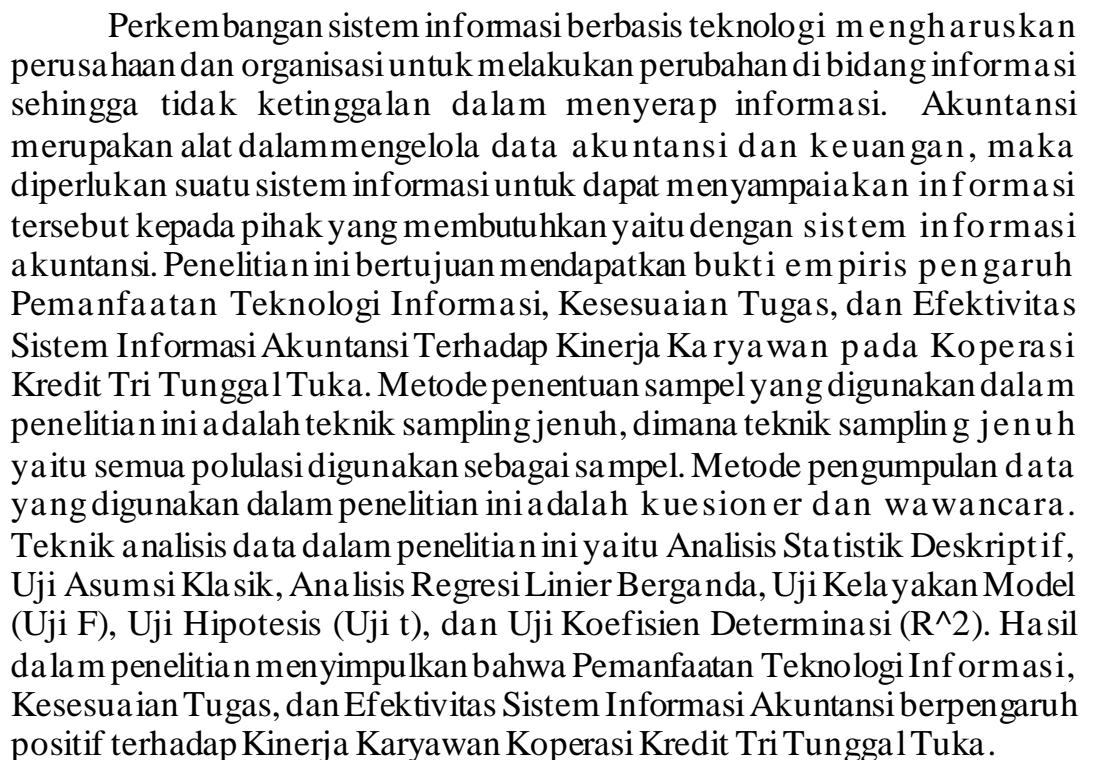 \\
\hline
\end{tabular}

Fakultas Ekonomidan Bisnis Universitas Udayana, Ba li, Indonesia ${ }^{2}$

Email: pande_dwiana@unud.ac.id 


\section{PENDAHULUAN}

Perkembangan teknologi dan informasi memberikan banyak manfaat dan membantu masyarakat dalam berkomunikasi dan bersosialisasi dengan siapa saja dan dimana saja. Adanya perkembangan system informasi berbasis teknologi ini menciptakan terjadinya persaingan antar perusahaan. Karena perubahan ekonomi global menuntut perusahaan untuk mengembangkan perusahaannya agar dapat bersaing satu sama lain (Alannita \& Suaryana, 2014). Dalam menyerap infornasi, perusahaan tidak hanya sekedar tahu namun harus mampu memahami informasi tersebut. Hal ini dikarenakan dalam persaingan, pihak yang mengetahui informasi lebih awal yang akan menjadi pemenang (Mahendra \& Windhiyani, 2016).

Salehi (2010) menyebutkan bahwa akuntansi merupakan mediator informasi, karena dapat memberikan informasi keadaan perusahaan. Dalam pengelolaan data akuntansi agar informasi yang dibutuhkan oleh pihak-pihak tertentu dapa tersampaikan maka diperlukan adanya system informasi akuntansi. Kelengkapan system informasi memberikan keunggulan kompetitif bagi suatu organisasi bisnis. Untuk dapat meninkatkan kualitas perusahaan maka diperlukan adanya kinerja karyawan. Lindawati \& Salamah (2011) mengemukakan bahwa kinerja individu mengacu pada standar perusahaan yang dapat dicapai/diraih oleh individu. Pentingnya memperhatikan kinerja individu karena akan mempengaruhi keberlangsungan dan kesuksesan perusahaan (Astuti \& Dharmadiaksa, 2014).

Menurut Retriana (2013), Pemanfaat tekologi informasi secar efektif dapat dilakukan apabila semua anggota organisasi dapat menggunakannya dengan baik. Pemanfaatan teknologi informasiyang baik akan turut meningkatkan kinerja dari individu tersebut. Sugiantara \& Putra (2017) dalam penelitiannya menemukan bahwa pemanfaatan teknologi informasi berpengaruh positif dan signifikan terhadap kinerja karyawan. Dalam kerangka teori TAM, kecanggihan teknologi informasi berkaitan dengan persepsi kemanfaatan (usefulness) dimana kecanggihan teknologi informasi yang tinggi akan berujung pada tingkat kepercayaan yang tinggi terhadap kemanfaatan pemakai sebuah system.

Sutra (2020) menyebutkan bahwa kinerja karyawan dapa dipengaruhi ole kesesuaian tugas. Kebutuhan tugas harus disesuaikan dengan kemampuan individu, serta adanya teknologi informasi yang tepat. Ketiha hal ini merupakan satu kesatuan yang saling berhubungan. Apabila diantara ketiga hal tersebut tidak berjalan selaras maka akan mengurangi keberhasilan pekerjaan. Dalam meningkatkan kinerja umumnya dilakukan dengan adanya evaluasi pemakai atas kesesuaian tugas dengan teknologi yang digunakan. Evaluasi pemakai dapat dijadikan tolok ukur apakah system informasi yang digunakan telah sesuai, yang dilakukan dengan menghubungkan antara kesesuaian tugas dan teknologi tersebut (Marlinawati, 2013). Hasil penelitian Widiantari \& Widhiyani (2019) menemukan bahwa kesesuaian tugas berpengaruh positif terhadap kinerja karyawan. Dalam teori TPC, agar suatu teknologi mempunyai dampak positif pada kinerja individual maka teknologi tersebut harus digunakan (Utilized) dan sesuai (fit) dengan tugas-tugas yang mendukungnya.

Sistem informasi akuntansi merupakan suatu proses yang melakukan pengumpulan, pencatatan, penyimpanan dan memproses akuntansi serta data lainnya untuk menghasilkan informasi bagi pengambil keputusan. Proses sistem informasi akuntansi dapat berupa proses manual, komputer atau gabungan keduanya(Romney \& Steinbart, 2018). Sistem informasi akuntansi bertujuan untu meningkatkan kualitas informasi yang dihasilkan system. Model Technology Acceptance Model

Pengaruh Pemanfaatn TI, Kesesuaian Tugas, dan Efektivitas SIA Terhadap Kinerja Karyawan Pada KOPDIT 
menggambarkan bahwa pengunaan sistem informasi akan meningkatkan kinerja individu atau karyawan. Hasil penelitian yang dilakukan Arsiningsih (2015) menyimpulkan bahwa efektivitas penerapan sistem informasi akuntansi berpengaruh positif terhadap kinerja karyawan.

Koperasi Kredit Tri Tunggal Tuka bisa dikatakan sedang berkembang dari sisi asetnya, tetapi pelayanannya dalam bidang teknologi informasi yaitu sistem informasi serta transaksi online sempat tertinggal beberapa waktu belakangan. Pelayanan transaksi pada era digital ini mengharuskan kegiatan transaksi bisa dilakukan dengan mudah secara online. Koperasi Kredit Tri Tunggal Tuka selain mengembangkan layanan sistem informasi berbasis web juga memerlukan pemasukan yang berasal dari bunga pinjaman anggota untuk kelancaran kegiatan koperasi. Loan to Deposit Ratio (LDR) merupakan salah satu rasio yang digunakan untuk mengukur likuiditas yaitu rasio pinjaman yang diberikan koperasi dan jumlah dana yang disediakan koperasi. Berdasarkan informasi yang diperoleh dari Koperasi Kredit Tri Tunggal Tuka, terjadi penurunan Loan to Deposit Ratio dalam lima tahun terakhir sehingga mengharuskan Koperasi untuk meningkatkan lagi kinerja karyawan terutama dalam penerapan sistem informasi berbasis web serta peningkatan pinjaman yang diberikan kepada anggota sehingga dapat menunjang pertumbuhan koperasi kedepannya.

Terdapat beberapa teori yang digunakan dalam penelitian ini, yaitu Teori TPC (Technology to Performance Chain) yang menjelaskan teknologi informasi berperan dalam meningkatkan kinerja, baik di tingkat individu maupun organisasi jika dimanfaatkan dengan maksimal. Penelitian Kasandra \& Juliarsa (2016) menyatakan bahwa pemanfaatan teknologi informasi berpengaruh signifikan pada kinerja karyawan. Adanya pemanfaatan teknologi informasi memudahkan karyawan dalam pengolahan data, mengakses data dan meningkatkan efisiensi.

Technology-to-Performance Chain adalah teori yang berhibungan dengan sikap pemakai dengan kesesuaian tugas teknologi. Konsep dimensi kesesuaian pekerjaan (job fit) mirip dengan kegunaan persepsian (parceived usefulness) yang dikenalkan oleh (Davis, 1989) di model penerimaan teknologi (tecnology acceptance model) mereka. Widiantari \& Widhiyani (2019) menyatakan bahwa kesesuaian tugas berpengaruh positif terhadap kinerja karyawan. Hal ini berarti semakin sesuai tugas yang dikerjakan dengan kemampuan individual dan teknologi yang digunakan, maka kinerja individu tersebut akan semakin meningkat.

Berdasarkan teori Technology Acceptance Model, seorang karyawan sebagai pengguna sistem informasi akuntansi mampu menerima manfaat dan merasakan kemudahan dari adanya suatu sistem informasi akuntansi, maka kinerja tentu akan dipermudah dengan adanya suatu sistem tersebut (Fatmayoni \& Yadnyana, 2017). Hal ini diperkuat dengan penelitian yang dilakukan oleh (Arsiningsih dkk., 2015) yang menunjukkan efektivitas sistem informasi akuntansi di perusahaan tidak hanya untuk meningkatkan efisiensi, tetapi juga mendukung terjadinya proses kinerja yang lebih efektif.

Berdasarkan penjelasan rumusan masalah, dan penelitian-penelitian sebelumnya, dapat dirumuskan beberapa hipotesis penelitian sebagai berikut: $\mathrm{H}_{1}$ : Pemanfaatan teknologi informasi berpengaruh positif pada kinerja karyawan, $\mathrm{H}_{2}$ : Kesesuaian tugas berpengaruh positif pada kinerja karyawan, H3 : Efektivitas sistem informasi akuntansi berpengaruh positif pada kinerja karyawan 


\section{METODE PENELITIAN}

Penelitian ini menjelaskan pengaruh variabel independen pada variabel dependen yakni untuk mengetahui pengaruh pemanfaatan teknologi informasi, kesesuaian tugas, dan efektivitas sistem informasi akuntansi terhadap kinerja karyawan. Penelitian dilakukan di Koperasi Kredit Tri Tunggal Tuka, yang berpusat di Jalan Raya Tuka, No. 30 Dalung, Kecamatan Kuta Utara, Kabupaten Badung, Bali. Jenis data yang digunakan ada 2 (dua) yaitu data kualitatif berupa visi dan misi koperasi, struktur organisasi dan tugas dari masing-masing bagian dalam Lembaga, serta data kuantitatif berupa aset, loan to deposit ratio, jumlah karyawan dan data skor nilai dari jawaban kuesioner yang telah diisi oleh responden. Sumber data penelitian adalah data primer, yang merupakan jawaban responden dari kuesioner yang telah disebarkan. Populasi pada penelitian ini adalah seluruh karyawan Koperasi Kredit Tri Tunggal Tuka yang menggunakan sistem informasi akuntansi dan teknologi informasi. Metode penentuan sampel yang digunakan dalam penelitian ini adalah teknik sampling jenuh, dimana populasi digunakan sebagai sampel, sehingga diperoleh sampel sebanyak 68 orang. Data penelitian dikumpulkan melalui beberapa metode, yakni penyebaran kuesioner, dan melakukan wawancara dengan responden. Data dianalisis dengan menggunakan Teknik analisis regresi linier berganda, namun sebelumnya akan dilakukan uji instrument, uji statistic deskriptif, uji asumsi klasik, dan terakhir dilakukan uji hipotesis.

\section{HASIL DAN PEMBAHASAN}

Berdasarkan hasil penelitian diperoleh bahwa jenis kelamin responden sebagian besar adalah perempuan sebanyak 38 orang (58,46 persen) dan sisanya laki-laki sebanyak 27 orang (41,54 persen). Responden yang berusia $<21$ tahun sebanyak 1 orang (1,54 persen), usia 21-30 tahun sebanyak 21 orang (32,31 persen), usia 31-40 tahun sebanyak 21 orang (32,31 persen), dan usia di atas 40 tahun sebanyak 22 orang $(33,85$ persen). Sebagian besar responden memiliki tingkat pendidikan SMA sebanyak 40 orang (61,54 persen), sedangkan sisanya memiliki tingkat pendidikan Diploma sebanyak 5 orang (7,69 persen), S1 sebanyak 19 orang (29,23 persen), dan S2 sebanyak 1 orang (1,54 persen). Masa kerja responden yang paling banyak jatuh pada kelompok 5-10 tahun yaitu sebanyak 31 orang (47,69 persen) dari total responden, sedangkan sisanya kurang dari 5 tahun sebanyak 21 orang $(32,31$ persen), 10-20 tahun sebanyak 12 orang (18,46 persen) dan lebih dari 20 tahun sebanyak 1 orang $(1,54$ persen).

Berdasarkan hasil uji validitas yang telah dilakukan, diketahui bahwa seluruh kuesioner yang merupakan Instrumen penelitian yang digunakan untuk mengukur variabel pemanfaatan teknologi informasi, kesesuaian tugas, efektivitas SIA dan kinerja karyawan memiliki nilai koefisien korelasi dengan skor total seluruh item pertanyaan dan pernyataan lebih besar dari 0,30. Hal ini mengindikasikan bahwa butir-butir pertanyaan dan pernyataan dalam instrumen penelitian tersebut valid dan layak digunakan sebagai instrumen penelitian.

Berdasarkan hasil uji reabilitas dengan menggunakan uji statistik Cronbach's Alpha, diketahui bahwa seluruh instrumen penelitian memiliki koefisien Cronbach's Alpha lebih dari 0,70. Maka, dapat

Pengaruh Pemanfaatn TI, Kesesuaian Tugas, dan Efektivitas SIA Terhadap Kinerja Karyawan Pada KOPDIT 
dinyatakan bahwa seluruh variabel telah memenuhi syarat reliabilitas atau kehandalan sehingga dapat digunakan untuk melakukan penelitian.

Tabel 1.

Hasil Statistik Deskriptif

\begin{tabular}{lccccc}
\hline \multicolumn{1}{c}{ Variabel } & N & Minimum & Maximum & Mean & Std.Devitiation \\
\hline Pemanfaatan Teknologi & 65 & 21 & 30 & 27,26 & 2,231 \\
Informasi & 65 & 19 & 25 & 22,37 & 1,799 \\
Kesesuaian Tugas & 65 & 19 & 25 & 22,28 & 1,883 \\
Efektivitas SIA & 65 & 19 & 25 & 22,38 & 2,067 \\
Kinerja Karyawan & & & &
\end{tabular}

Sumber: Data Penelitian, 2021

Berdasarkan hasil uji, statistik deskriptif dari masing-masing variabel dapat diuraikan sebagai berikut: Variabel pemanfaatan teknologi informasi $\left(X_{1}\right)$ memiliki nilai minimum sebesar 21 dengan nilai maksimum sebesar 30 , dan nilai rata-rata 27,26. Nilai rata-rata sebesar 27,26 mendekati nilai maksimal yang berarti bahwa pemanfaatan teknologi informasi tersebut tergolong tinggi. Standar deviasi variabel pemanfaatan teknologi informasi sebesar 2,231 yang lebih kecil dari nilai rata-rata, artinya terdapat perbedaan standar nilai pemanfaatan teknologi informasi dibandingkan nilai rata-rata sebesar 2,231. Variabel kesesuaian tugas $\left(\mathrm{X}_{2}\right)$ memiliki nilai minimum sebesar 19 dengan nilai maksimum sebesar 25, dan nilai rata-rata 22,37. Nilai rata-rata sebesar 22,37 mendekati nilai maksimal yang berarti bahwa kesesuaian tugas tersebut tergolong tinggi. Standar deviasi variabel kesesuaian tugas sebesar 1,799 yang lebih kecil dari nilai rata-rata, artinya terdapat perbedaan standar nilai kesesuaian tugas dibandingkan nilai rata-rata sebesar 1,799.

Variabel efektivitas sistem informasi akuntansi $\left(\mathrm{X}_{3}\right)$ memiliki nilai minimum sebesar 19 dengan nilai maksimum sebesar 25 , dan nilai rata-rata 22,28 . Nilai rata-rata sebesar 22,28 mendekati nilai maksimal yang berarti bahwa efektivitas sistem informasi akuntansi tersebut tergolong tinggi. Standar deviasi variabel efektivitas sistem informasi akuntansi sebesar 1,883 yang lebih kecil dari nilai rata-rata, artinya terdapat perbedaan standar nilai efektivitas sistem informasi akuntansi dibandingkan nilai rata-rata sebesar 1,883. Variabel kinerja karyawan (Y) memiliki nilai minimum sebesar 19 dengan nilai maksimum sebesar 25 , dan nilai rata-rata 22,38. Nilai rata-rata sebesar 22,38 mendekati nilai maksimal yang berarti bahwa kinerja karyawan tersebut tergolong tinggi. Standar deviasi variabel kinerja karyawan sebesar 2,067 yang lebih kecil dari nilai rata-rata, artinya terdapat perbedaan standar nilai kinerja karyawan dibandingkan nilai rata-rata sebesar 2,067.

Uji normalitas bertujuan untuk menguji apakah dalam model regresi memiliki distribusi normal atau tidak. Untuk mendeteksi normalitas data digunakan Kolmogorov-Smirnov dengan kriteria jika Asymp. Sig (2-tailed) lebih besar dari level of significant yang digunakan yaitu 5 persen $(0,05)$, maka dapat disimpulkan bahwa data berdistribusi normal, begitu pula sebaliknya. Hasil uji normalitas didapat nilai signifikansi sebesar 0,200, yang berarti nilai signifikansi uji Kolmogorov-Smirnov lebih dari 0,05 maka dapat disimpulkan bahwa model persamaan regresi tersebut berdistribusi normal.

Pengaruh Pemanfaatn TI, Kesesuaian Tugas, dan Efektivitas SIA Terhadap Kinerja Karyawan Pada KOPDIT 
Uji multikolinearitas bertujuan menguji apakah dalam regresi ditemukan adanya korelasi antar variabel bebas. Multikolinieritas dapat dilihat dari nilai tolerance dan nilai variance inflation factor (VIF). Adapun kriteria pengujiannya adalah jika nilai tolerance $>10$ persen $(0,10)$ dan nilai VIF $<10$, maka dapat dikatakan bahwa tidak terjadi gejala multikolinearitas dan begitu pula sebaliknya. Hasil uji multikolinearitas diperoleh bahwa variabel pemanfaatan teknologi informasi, kesesuaian tugas, dan efektivitas SIA seluruhnya memiliki nilai tolerance $>0,10$ dan nilai VIF $<10$. Hal ini berarti ketig a variabel pada persamaan regresi yang ada terbebas dari gejala multikolinieritas.

Uji heteroskedastisitas bertujuan menguji apakah dalam regresi terjadi ketidaksamaan varians dari residual satu pengamatan ke pengamatan yang lain, dengan menggunakan Uji Glejser. Adapun kriteria pengujian jika nilai signifikansinya lebih besar dari 0,05 maka tidak terjadi heteroskedastisitas dan berlaku sebaliknya. Berdasarkan hasil uji heteroskedastisitas diketahui bahwa signifikansi untuk variabel pemanfaatan teknologi informasi, kesesuaian tugas, dan efektivitas sistem informasi akuntansi memiliki nilai yang lebih besar dari 0,05 . Hal ini berarti bahwa variabel pada persamaan regresi terbebas dari gejala heteroskedastisitas.

Tabel 2.

Hasil Analisis Regresi Linear Berganda

\begin{tabular}{lccccc}
\hline & \multicolumn{9}{c}{$\begin{array}{c}\text { Standardized } \\
\text { Unstandardized Coefficients }\end{array}$} & Coefficients & & \\
\cline { 2 - 4 } Model & $\mathbf{B}$ & Std. Error & Beta & T & Sig. \\
\hline (Constant) & $-0,185$ & 2,404 & & $-0,077$ & 0,939 \\
Pemanfaatan Teknologi & 0,252 & 0,102 & 0,272 & 2,473 & 0,016 \\
Informasi $\left(\mathrm{X}_{1}\right)$ & 0,400 & 0,134 & 0,348 & 2,977 & 0,004 \\
KesesuaianTugas $\left(\mathrm{X}_{2}\right)$ & 0,304 & 0,117 & 0,277 & 2,589 & 0,012 \\
Efektivitas SIA $\left(\mathrm{X}_{3}\right.$ & & & &
\end{tabular}

Sumber: Data Penelitian, 2021

Berdasarkan hasil pengujian, dapat disusun persamaan regresi sebagai berikut:

$$
\hat{Y}=-0,185+0,252 X_{1}+0,400 X_{2}+0,304 X_{3}
$$

Keterangan:

$\hat{\mathrm{Y}} \quad=$ Kinerja Karyawan

$\alpha \quad=$ Konstanta

$\beta_{1}-\beta_{3} \quad=$ Koefisien regresi untuk masing-masing variabel independen

$\mathrm{X}_{1} \quad=$ Pemanfaatan Teknologi Informasi

$\mathrm{X}_{2} \quad=$ Kesesuaian Tugas

$\mathrm{X}_{3} \quad=$ Efektivitas Sistem Informasi Akuntansi

Berdasarkan persamaan diatas, maka dapat dijelaskan bahwa: Nilai konstanta sebesar -0,185 namun tidak signifikan karena memiliki nilai signifikansi 0,939 yang lebih besar dari alpha $(0,05)$. Hal ini berarti bahwa pemanfaatan teknologi informasi memiliki nilai sebesar nol satuan persepsi dengan asumsi semua variabel bebas lainnya bernilai nol. Nilai koefisien pemanfaatan teknologi informasi $\left(\mathrm{X}_{1}\right)$ yaitu 0,252 memiliki arti bahwa pemanfaatan teknologi informasi memiliki hubungan positif dengan kinerja karyawan. Apabila pemanfaatan teknologi informasi $\left(\mathrm{X}_{1}\right)$ meningkat sebesar satu

Pengaruh Pemanfaatn TI, Kesesuaian Tugas, dan Efektivitas SIA Terhadap Kinerja Karyawan Pada KOPDIT 
satuan persepsi, maka kinerja karyawan $(\mathrm{Y})$ akan meningkat sebesar 0,252 satuan persepsi dengan asumsi variabel bebas lainnya konstan. Nilai koefisien kesesuaian tugas $\left(\mathrm{X}_{2}\right)$ yaitu 0,400 memiliki arti bahwa kesesuaian tugas memiliki hubungan positif dengan kinerja karyawan. Apabila kesesuaian tugas $\left(\mathrm{X}_{2}\right)$ meningkat sebesar satu satuan persepsi, maka kinerja karyawan $(\mathrm{Y})$ akan meningkat sebesar 0,400 satuan persepsi dengan asumsi variabel bebas lainnya konstan. Nilai koefisien efektivitas sistem informasi akuntansi $\left(\mathrm{X}_{3}\right)$ yaitu 0,304 memiliki arti bahwa efektivitas sistem informasi akuntansi memiliki hubungan positif dengan kinerja karyawan. Apabila efektivitas sistem informasi akuntansi $\left(\mathrm{X}_{3}\right)$ meningkat sebesar satu satuan persepsi, maka kinerja karyawan $(\mathrm{Y})$ akan meningkat sebesar 0,304 satuan persepsi dengan asumsi variabel bebas lainnya konstan.

Berdasarkan hasil pengujian diperoleh nilai adjusted $\mathrm{R}^{2}$ sebesar 0,573 . Nilai ini mempunyai arti bahwa sebesar 57,3 persen variasi kinerja karyawan dapat dijelaskan oleh variasi-variabel bebas yang dimasukkan dalam model, sedangkan sisanya sebesar 42,7 persen djelaskan oleh faktor lain yan g tidak dimasukkan dalam model

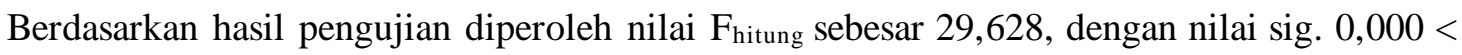
0,05 . Hal ini berarti bahwa terdapat pengaruh simultan yang signifikan dari variabel-variabel bebas terhadap variabel terikat. Dengan kata lain model regresi layak untuk digunakan.

Berdasarkan hasil pengujian dalam penelitian ini, didapatkan hasil bahwa pemanfaatan teknologi informasi mempunyai pengaruh positif terhadap kinerja karyawan. Hal tersebut diketahui dari dari tingkat signifikansi $\mathrm{X}_{1}$ (pemanfaatan teknologi informasi) sebesar 0,016 $<0,05$. Hasil pengujian tersebut menunjukkan bahwa hipotesis pertama $\left(\mathrm{H}_{1}\right)$, pemanfaatan teknologi informasi mempunyai pengaruh yang positif terhadap kinerja karyawan, diterima. Hal ini berarti bahwa semakin tinggi tingkat pemanfaatan teknologi informasi menyebabkan peningkatan kinerja karyawan pada Koperasi Kredit Tri Tunggal Tuka.

Hasil penelitian ini mendukung teori Technology Acceptance Model, yang menyatakan bahwa kecanggihan teknologi informasi berkaitan dengan persepsi kemanfaatan (usefulness) dimana kecanggihan teknologi informasi yang tinggi akan berujung pada tingkat kepercayaan yang tinggi terhadap kemanfaatan pemakai sebuah sistem. Hasil penelitian ini sejalan dengan penelitian sebelumnya yang dilakukan oleh (Sugiantara dan Putra, 2017) yang menyatakan bahwa pemanfaatan teknologi informasi berpengaruh positif terhadap kinerja karyawan. Hasil penelitian (Astuti dan Dharmadiaksa, 2014) menyatakan pemanfaatan teknologi informasi memiliki pengaruh yang positif dan signifikan terhadap kinerja karyawan..

Berdasarkan hasil pengujian dalam penelitian ini, didapatkan hasil bahwa kesesuaian tugas mempunyai pengaruh positif terhadap kinerja karyawan. Hal tersebut diketahui dari dari tingkat signifikansi $\mathrm{X}_{2}$ (kesesuaian tugas) sebesar $0,004<0,05$. Hasil pengujian tersebut menunjukkan bahwa hipotesis kedua $\left(\mathrm{H}_{2}\right)$, kesesuaian tugas mempunyai pengaruh yang positif terhadap kinerja karyawan, diterima. Hal ini berarti bahwa semakin tinggi tingkat kesesuaian tugas menyebabkan peningkatan kinerja karyawan pada Koperasi Kredit Tri Tunggal Tuka.

Hasil penelitian ini mendukung teori Technology-to-Performance Chain, yang menyatakan bahwa agar suatu teknologi mempunyai dampak positif pada kinerja individual maka teknologi tersebut harus digunakan (Utilized) dan sesuai (fit) dengan tugas-tugas yang mendukungnya. Hasil

Pengaruh Pemanfaatn TI, Kesesuaian Tugas, dan Efektivitas SIA Terhadap Kinerja Karyawan Pada KOPDIT 
penelitian ini sejalan dengan penelitian sebelumnya yang dilakukan oleh Sugiantara dan Putra (2017) menyatakan bahwa kesesuaian tugas berpengaruh positif terhadap kinerja karyawan. Hasil penelitian Widiantari dan Widhiyani (2019) menyatakan bahwa kesesuaian tugas berpengaruh positif terhadap kinerja karyawan. Hal ini berarti semakin sesuai tugas yang dikerjakan dengan kemampuan individual dan teknologi yang digunakan, maka kinerja individu tersebut akan semakin meningkat.

Berdasarkan hasil pengujian dalam penelitian ini, didapatkan hasil bahwa efektivitas sistem informasi akuntansi mempunyai pengaruh positif terhadap kinerja karyawan. Hal tersebut diketahui dari dari tingkat signifikansi $\mathrm{X}_{3}$ (efektivitas sistem informasi akuntansi) sebesar 0,012<0,05. Hasil pengujian tersebut menunjukkan bahwa hipotesis ketiga $\left(\mathrm{H}_{3}\right)$, efektivitas sistem informasi akuntansi mempunyai pengaruh yang positif terhadap kinerja karyawan, diterima. Hal ini berarti bahwa semakin tinggi tingkat efektivitas sistem informasi akuntansi menyebabkan peningkatan kinerja karyawan pada Koperasi Kredit Tri Tunggal Tuka.

Hasil penelitian ini mendukung teori Technology Acceptance Model, yang menyatakan bahwa penggunaan sistem informasi akan meningkatkan kinerja individu atau karyawan. Hasil penelitian ini sejalan dengan penelitian sebelumnya yang dilakukan oleh Astuti dan Dharmadiaks (2014) yang menyatakan bahwa efektivitas sistem informasi akuntansi memiliki pengaruh yang positif dan signifikan terhadap kinerja karyawan. Penelitian ini juga sejalan dengan penelitian yang dilakukan oleh Sugiantara dan Putra (2017) menyatakan bahwa efektivitas sistem informasi akuntansi berpengaruh positif terhadap kinerja karyawan.

Secara teoritis penelitian ini menunjukkan bahwa pemanfaatan teknologi informasi, kesesuaian tugas, dan efektivitas sistem informasi akuntansi berpengaruh positif terhadap kinerja karyawan dan mendukung teori Technology Acceptance Model serta Technology-to-Performance Chain.

Secara praktis, penelitian ini diharapkan bagi karyawan Koperasi Kredit Tri Tunggal Tuka agar lebih memperhatikan kinerjanya terkait pemanfaatan teknologi informasi, kesesuaian tugas, dan efektivitas sistem informasi akuntansi sehingga perkembangan Koperasi Kredit Tri Tunggal Tuka menjadi lebih baik lagi. Selain itu, penelitian ini juga diharapkan dapat memberikan suatu informasi tambahan untuk penelitian berikutnya guna penyempurnaan penelitian mengenai hal sejenis.

\section{SIMPULAN DAN SARAN}

Berdasarkan hasil pembahasan maka dapat disimpulkan bahwa pemanfaatan teknologi informasi berpengaruh positif terhadap kinerja karyawan pada Koperasi Kredit Tri Tunggal Tuka. Hal ini berarti bahwa semakin tinggi tingkat pemanfaatan teknologi informasi menyebabkan peningkatan kinerja karyawan pada Koperasi Kredit Tri Tunggal Tuka; Kesesuaian tugas berpengaruh positif terhadap kinerja karyawan pada Koperasi Kredit Tri Tunggal Tuka. Hal ini berarti bahwa semakin tinggi tingkat kesesuaian tugas menyebabkan peningkatan kinerja karyawan pada Koperasi Kredit Tri Tunggal Tuka; dan Efektivitas sistem informasi akuntansi berpengaruh positif terhadap kinerja karyawan pada Koperasi Kredit Tri tunggal Tuka. Hal ini berarti bahwa semakin tinggi tingkat efektivitas sistem informasi akuntansi menyebabkan peningkatan kinerja karyawan pada Koperasi Kredit Tri Tunggal Tuka.

Pengaruh Pemanfaatn TI, Kesesuaian Tugas, dan Efektivitas SIA Terhadap Kinerja Karyawan Pada KOPDIT 
Berdasarkan hasil penelitian dan simpulan diatas, maka dapat diajukan saran bagi Koperasi Kredit Tri Tunggal Tuka agar sistem informasi akuntansi yang digunakan juga harus menyediakan serta menyajikan data yang lebih rinci dan lengkap. Tujuannya untuk memudahkan karyawan menyelesaikan tugas pada setiap bidang pekerjaan masing-masing dalam meningkatkan perkembangan kinerja karyawan di Koperasi Kredit Tri Tunggal Tuka sehingga selalu dipercaya oleh anggota dan masyarakat sebagai lembaga yang baik. Keterbatasan dalam penelitian ini hendaknya dapat lebih disempurnakan lagi pada peneliti selanjutnya yaitu dengan tidak membatasi daerah pengambilan sampel hanya pada satu lembaga saja, sehingga dapat mewakili populasi yang lebih luas.

\section{REFERENSI}

Alannita, N.P., \& Suaryana, I. G. N. A. (2014). Universitas Udayana, 2014, Pengaruh Kecanggihan Teknologi Informasi, Partisipasi Manajemen, Dan Kemampuan Teknik Pemakai Sistem teknologi informasi Pa da Kinerja Individu. E-Jurnal Akuntansi Universitas Udayana, 6(1),33-45

Arsiningsih Febri, Gede Diatmika, S. D. (2015). Pengaruh Penggunaan Teknologi Informasi, Efektivitas Sistem Informasi Akuntansi, Kepercayaan Atas Sistem Informasi Akuntan si, Sistem Pengendalia n Intern Terhadap Kinerja Karyawan Pada Bank Perkreditan Rakyat Di Kabupaten Buleleng Dan Bangli. JIMAT (Jurnal Ilmiah Mahasiswa Akuntansi S1), 3(1), 1-10.

Astuti, N. M. M. P., \& Dharmadiaksa, I. B. (2014). Pengaruh Efektivitas Penerapan Sistem Informasi Akuntansi, Pemanfaatan dan Kesesuaian Tugas pada Kinerja Karyawan. E-Jurnal Akuntansi Universitas Udayana, 9(2), 373-384

Davis, F. D. (1989). Technology Acceptance Model: TAM. Al-Suqri, MN, Al-Aufi, AS: Information Seeking Behavior and TechnologyAdoption, S, 2(1), 205-219

Juliarsa, dan Kasandra. (2016). Pengaruh Kualitas Penerapan Sia, Pemanfaatan Dan Kep ercayaan Tek nolo gi Informasi Pada Kinerja Karyawan. E-Jurnal Akuntansi, 14(1), 539-547

Linda wati, H., \& Sa la mah, I. (2011). Pemanfaatan Sistem Informasi dan Teknologi In formasi Pen garuh nya Terhadap Kinerja Individual Karyawan. Jurnal Akuntansi Dan Keuangan, 14(1), 56-67. https://doi.org/10.9744/jak.14.1.56-68

Mahendra, I. G. A., \& Widhiyani, N. L. S. (2016). Kemampuan Teknik Pemakai Memoderasi Pengaruh Efektivitas Sistem Informasi Akuntansi Pada Kinerja Individual Koperasi Simpan Pinjam Di Kecamatan Tabanan. E-JurnalAkuntansi Universitas Udayana, 15(3), 1886-1912

Retria na. (2013). Pengaruh Pemanfaatan Teknologi Informasi Terhadap Kinerja Individual Pada Kantor Dinas Kependudukan Dan Pencatatan Sipil Kabupaten Wonogiri

Sa lehi, M., Rostami, V., \& Mogadam, A. (2010). Usefulness of accounting inform ation sy stem in em erging economy: Empirical evidence of Iran. International Journal of Economics and Finance, 2 (2), 186-195

Sugiantara dan Putra. (2017). Analisis Faktor-Faktor Yang Mempengaruhi Kinerja Karyawan Di Dispenda Kota Denpasar. E-Jurnal Akuntansi, 20(3), 2509-2538

Sutra, P. (2020). Pengaruh Efektivitas, Pemanfaatan dan Kesesuaian Tugas Penerapan Sistem Informasi Akuntansi Terhadap Kinerja Karyawan KoperasiDi Desa Panjer. TIERS Information Technology Journal, 1(1), 19-24

Widiantari, N. P., \& Sari Widhiyani, N.L. (2019). Pengaruh Efektivitas Penerapan Sistem Informasi Akuntansi, Kesesuaian Tugas dan Kenyamanan Fisik Pa da Kinerja Karyawan LPD. E-Jurnal Akuntansi, 29(1), 258. https://doi.org/10.24843/eja.2019.v29.i01.p17

Yadnyana, F. dan. (2017). Pengaruh Efektivitas Sia Dan Penggunaan Teknologi Informasi Pada Kinerja Individual Dengan Insentif Karyawan Sebagai Pemoderasi. E-JurnalAkuntansi, 19(3), 2175-2204

Yasa, G. E., \& Sari, M. M. R. (2020). Analysis of Market Reaction on Wall Street Attenuation in Indonesia. American

Pengaruh Pemanfaatn TI, Kesesuaian Tugas, dan Efektivitas SIA Terhadap Kinerja Karyawan Pada KOPDIT

Tri Tunggallka,

Agustinus I Ketut Alexsdipa dan I Made Pande Dwiana Putra 
Journal of Humanities and Social Sciences Research (AJHSSR), 4(8), 475-481.

Xiao, X., \& Gao, Y. (2017). An Event Study of The Effects of Regulatory Changes on The Food Industry. China Agricultural Economic Review, 9(1), 81-92. https://doi.org/https://doi.org/10.1108/CAER-01-2014-0006 